\title{
MOVING UP ON SOLAR INDUSTRY VALUE CHAIN: A RESPOND TO WORLD BANK'S PRESCRIPTION FOR MALAYSIA
}

\author{
${ }^{1}$ Bakhtyar, B., ${ }^{2}$ Ch. Lim, ${ }^{1}$ Y. Ibrahim, ${ }^{1}$ R. Islam and ${ }^{2}$ K. Sopian \\ ${ }^{1}$ School of Economy, Finance and Banking (SEFB), Collage of Business (COB), \\ University Utara Malaysia (UUM), 06010, Sintok, Malaysia \\ ${ }^{2}$ Solar Energy Research Institute (SERI), National University of Malaysia (UKM), \\ Level 3, PerpustakaanTun Sri Lanang, University Kebangsaan Malaysia, \\ 43600 Bangi, Selangor, Malaysia
}

Received 2014-05-27; Revised 2014-06-11; Accepted 2014-07-11

\begin{abstract}
The pressure due to the changes in supplying energy and its price in the international community is in such an extent that it encourages industrialized and developing countries in seeking self-sufficiency in energy production. As one of the leading in countries South East Asia Nations (ASEAN), Malaysia has taken planning and specific investment for the Solar Industry into consideration, besides paying attention to a variety of new and renewable energies. Given the diversity of processes in working on the development of Solar Industry, the World Bank has, through a comprehensive report, provided prescription with regard to the success of Malaysia in this industry. This paper presents an analysis of the study conducted by the World Bank. However, it shows that despite the detailed and comprehensive analysis of the value chain in the solar industry globally, assumptions and methods the World Bank about the solar industry in Malaysia suffers from several shortcomings and errors which can result in the lack of reliability and validity in its concluding remarks. Encouraging Malaysia to moving towards downstream industries for achieving more added value decrease the security of future investments in this industry in Malaysia also will raise the price of the final products and create crisis in the industry in the event of imbalance.
\end{abstract}

Keywords: Solar Technology, Value Chain, Solar Industry

\section{INTRODUCTION}

After more than a decade, the results obtained from utilizing the World Bank's prescriptions for dealing with the 1997 financial crisis in Southeast Asian countries have led these to practice the World Bank's proposals more carefully and certainly and skeptically. Malaysia's success in dealing with the crisis in 1997 also showed that the proposals by the International Monetary Fund and the World Bank in those days were not the only possible ways to pass the crisis (Sheng, 2009) and Malaysia's neighboring countries are still engaged in debts and consequences of that period. A report called"Moving up the Value Chain: A Study of Malaysia's Solar and Medical Device Industries "was released by the World Bank in July 2011, in which Solar Industry and medical devices are dealt with (Bradford et al., 2011). As long as this report emphasizes that the final proposals were obtained from a research process (Pages 3, 4, 11 and 12) and those involved in this project were academic researchers (Pages 3 ), this research seeks to examine the validity and operationalabilityof the World Bank's proposals through Corresponding Author: Bakhtyar, B., School of Economy, Finance and Banking (SEFB), Collage of Business (COB), University Utara Malaysia (UUM), 06010, Sintok, Malaysia 
analyzing the already conducted studies. Regarding the fact that the released report has jointly addressed the solar industry and medical devices and these two realms are two completely different specializations; this paper considers itself eligible only for research studies in the field of solar technologies in Malaysia.

\section{THE WORLD BANK'S STUDY IN A GLANCE}

The research presented by the World Bank has been conducted to promote Malaysia's Solar Industry and to increase the income in this sector. Accordingly, in the main objective of this research it has been delineated that Malaysiahas to move to an upper "value chain" to achieve a higher income, an issue which requires the manufacturing process to move towards higher added value (page 4). In other words and based on the offered explanations, Malaysia's main strategy for higher income is moving towards higher value-added goods and services produced in the solar sector. Therefore, the main research question of the World Bank study has been offered as (page 11):

\section{- "How can Malaysia extract greater added value from its manufacturing sector?"}

To find answer to this question, two other subquestions are asked as follows:

- "What is Malaysia's current position in the global value chain, what are the opportunities available to extract greater value added and what are the main challenges?"

And as second question:

- "For Malaysia to exploit the opportunities and overcome the challenges identified, what policy adjustments, if any, will be required?"

And regarding the research method for the project, on its page 11 it has been mentioned that:

- "The report sets out a conceptual framework, examines the global industry context, analyzes Malaysia's position in the global value chain, identifies industry opportunities and bottlenecks and suggests policy adjustments. "

In this study the World Bank reiterated that (Page 11):
- "This work can be updated, extended and replicated to other industries. The study also constitutes an attempt to promote a novel way of thinking about identifying and seizing value chain opportunities in ways that emphasize bottom-up, decentralized, collaborative and consultative approaches."

\section{TITLE OF THE STUDY}

The title of research conducted by the World Bank is as follows:

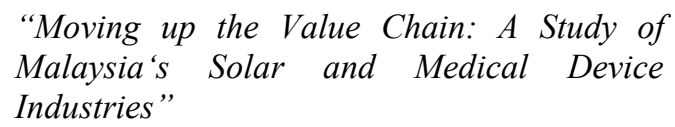

As it can be seen in this study, it addresses two completely separate and different industries, i.e., solar industry and medical devices. The point here is that how a team can be expert in providing guidelines for and studying two different industries with diverse processes and peculiarities. It seems that the writer of that has understood such discrepancies and therefore he has frequently tried to show that these industries are similar, about which we can refer to pages 4,5 and 11 of that report. This is despite the fact that policies made about the solar and medical industries as well as Malaysia's prospects for these industries are not the same. The responsibility that Malaysia has assigned to its solar industry via its roadmap for Malaysia's solar industry is not comparable and compatible with any industries in Malaysia (Sopian, 2010). Regarding that Malaysia's medical industry has its own peculiarities and its study requires expertise and specialization, we do not deal with it in this section and suffice to what we have already mentioned about it.

\section{MOVING UP THE VALUE CHAIN: LACK OF DISCUSSION}

The first chapter of the World Bank's report contends with "moving up the Value Chain" in which several interesting issues such as opportunities, bottlenecks and strategies for moving to upper Value Chains are mentioned. In this respect, however, noteworthy issues which are completely effective in achieving the final result are missing, which are dealt with below.

\subsection{Solar Industry and Political Economy}

It seems that the main error in the process of this research lies in its first hypothesis in that it has assumed 
moving to more added value as the key to achieving higher income and success of the country in solar industry. Hence, before making such an assumption this question must be raised: "Is increasing income the most basic and important goal that a country follows in production? Or are other factors like job creation or solidarity of country involved in determining the type and amount of a product as the national production?"On the other hand this question also arises: "what economic and political conditions does moving towards more addedvalue require?"

Although political economy has usually no role in economic formulas and equations, ignoring it will result in ignorance in a large part of the country's economic policies. From among the theories about political economy, paying attention to the Theory of Games can contribute greatly to the viewpoint of the World Bank report writers. Through an overall look in the World Bank report, it has been tried that the game rules be set in a way that Malaysia's solar industry and the available value chains in the world intersect at "Nash Equilibrium" and game elements offer a symmetrical game. Therefore, all presented data and statistics are assumed static and the writer believes that the conditions of production in Malaysia and around the world are always constant. A proof to this case is the analysis of Malaysia's solar industry and that report has been prepared based on existing companies in 2011 and only focuses on 5 companies, that is, First Solar, Q Cell, Sun Power, Tokyoma and Twin Creeks Technologies (p. 41). But only after a year, the number of solar manufacturing factories has reached 11 units in Malaysia and the investment has increased to RM21 billion from previous RM11.6 billion (appendix 1) (Bakhtyar et al., 2012a).

During this period, this has caused Malaysia to become the third largest producer in the solar industry after China and Germany and based on Malaysia Economic Transformation Malaysia will promote to the second ranked after China by 2020 (Fig. 1).

Accordingly, it is estimated that Malaysia, by relying on its renewable energies and especially the solar energy, will be able to create approximately 52000 new jobs by 2020. Regarding the creation of specialized jobs (Bakhtyar et al., 2012b), this issue is a very valuable for Malaysia.

Yet, the economic competition in solar industry in the world is not a Zero Sum game and this means that success in a game is not necessarily equivalent with defeating and as a result deleting a country from the competition. Besides, the game rules can change at any time by creating new policies and tariffs in each country (Shapley and Shubik, 1969). For example, creating a strong domestic market for two neighboring producers can push both countries towards a win-win game.

It seems that the solar industry in Malaysia together with its production chain in the world follow a random and asymmetric game with a non-zero sum. The game is essentially played in an atmosphere with no perfect knowledge; in such a way that in the most time scales and in different circumstances, there are not the same strategies for countries like Malaysia which are involved in the solar industry and in many cases the same thing cannot be prescribed for different problems. The profitability of a producing country such as China or an active chain in the solar industry does not necessarily mean losses for Malaysia (Bakhtyar et al., 2013a). Unpredictable events and circumstances constantly threaten the supply chain and value chain; and manufacturers and rivals are not completely aware of each other's situation and the global competition and policies which are ahead of them (Shapley and Shubik, 1969).

In this respect, however, macroeconomic issues such as national employment and attracting foreign investments as well as ideal issues like achieving maximal national self-sufficiency are under discussion and in many cases despite low economic profits in a chain of production, investment in and supporting the solar industry of Malaysia explain the current situation.

\subsection{Added Value Risks}

Of the things in which moving toward higher added value should be considered are risks arising from the move towards more added value and implementation of new strategies (Alexander, 2009).

Regarding the importance of risk assessment in the time for offering strategies for moving toward higher added value, there is this question that "how in the research presented by the World Bank the research objective is suddenly placed towards a higher added value without the assessment of risks in Malaysia's solar industry and solar industry's value chain?" To assess the available risks in moving toward more added values, the following questions must be answered before any efforts (Alexander, 2009): "How much should the added value rate be by taking the hedging strategies into account? How should shareholders or investors be reassured for adopting new strategies?" Calculating the added value via the risk management strategy will provide managers with clues by which given parameters can assess the viability of the discussed strategies. 
In this respect, there are numerous unsuccessful examples in industry and agriculture, all of which have occurred due to not tackling the future risks. As the World Bank has advised Malaysia, it is expected that this country will stop manufacturing cells due to their low added value and it will dedicate all its power to downstream industries.

The natural thing occurring in this market is that the downstream products that use Chinese cells increase. At this time, if China decides to reduce the price of its final products and offsets this loss by increasing the price of cells, it is obvious that the final products manufactured in Malaysia shortly lose their competitive strength and solar industry in this country quickly goes into bankruptcy.

\subsection{Value Chain Elasticity}

For the first time in 1985, Michael Porter introduced the term "value chain" in his best-selling book (Porter, 1985). He believes that the value chain is a chain of activities a company will perform in a particular industry, via which it can offer valuable services or products (Porter, 1985). One of the criteria for the evaluation of the value chain is the elasticity of a product in that value chain (Asche et al., 2002). Surprisingly, this 85-page report, does not even talk about the elasticity and its effect on the value chain once. In general, the relationship between being integrated in the supply chain and downstream is still seriously dependent on the elasticity of demands for produced goods. Also, from a technological point of view, compliment inputs have tight relation with the price elasticity of demand. The elasticity of final good is respectively in direct with elasticity of substitution among inputs (Hull, 2005).

A simple explanation for this section lies in the theory of consumption. Price elasticity of a product, either intermediate or a final, depends on the elasticity of substitute products. Experience has shown that in most cases severe external shocks are due to an increase in the price of intermediate goods. Figure 2 shows the rate of changes in the supply price such that by the rise in supplying solar cells, the supply curve moves to the right and naturally the prices in the market are reduced and by reducing the supply, the supply curve moves to the left and results in the increase in price of goods.

Regarding the fact that solar cells are the basic elements in solar industry and the sustainability of manufacturing firms is subject to utilizing solar cells and this fact that there are no alternative products for them, the graph for the elasticity of prices is presented in Fig. 3 .

As intermediate products, solar cells have very high elasticity such that slight changes in the production or supply of them will lead to a radical and rapid change in their price. Confluence of two earlier graphs results in Fig. 4 which clearly shows that if the cells supply declines for any reason, their price will increase more intensely.

With the sensitivity of solar cells in the process of production, familiarity of the Malaysian investors and manufacturers with the solar industry has caused that they themselves start producing solar cells and try to complete the production chain by accepting lower added value in the investment scale so that there would be a decrease in investment risks and future procurement in the market. With awareness of solar products dumping by China, investors in solar industry will therefore invest in such a way that they do not get influence and go bankrupt in the event of any increase in prices or artificial shortages in the market.

\subsection{Government role for protecting solar industry}

That is to say that governments' role in protecting domestic industries against dumping is very important such that the United States of America has, in this respect, recently (November 2012) issued some antidumping tariffs for the solar cells that are imported from China (Johnson and Sweet, 2012). Obviously, the United States of America is aware of the fact that after the bankruptcy of its solar cells factories, Chinese producers will no longer continue offering their cheap products and move towards the bankruptcy of their downstream manufacturers, too.

Being aware of this, however, banks and the government in Malaysia have started to offer extensive banking facilities to upstream industries and especially to cell manufacturers. Since its establishment in 2009, Sun Power Factory in Malaysia started working with a RM100 billion loan from the Malaysian government and at the time stated its main purpose as producing solar cells (Bakhtyar et al., 2013b). In 2012, the Malaysian government also announced it had increased the level loans for green technology industries from RM50 million to RM1.5 billion (Florida, 2010). The Malaysian government has also considered some other incentives such as tax exemptions for related industries, which have made investments in upstream solar industry reasonable. 
Bakhtyar B. et al. / American Journal of Economics and Business Administration 6 (2): 72-80, 2014

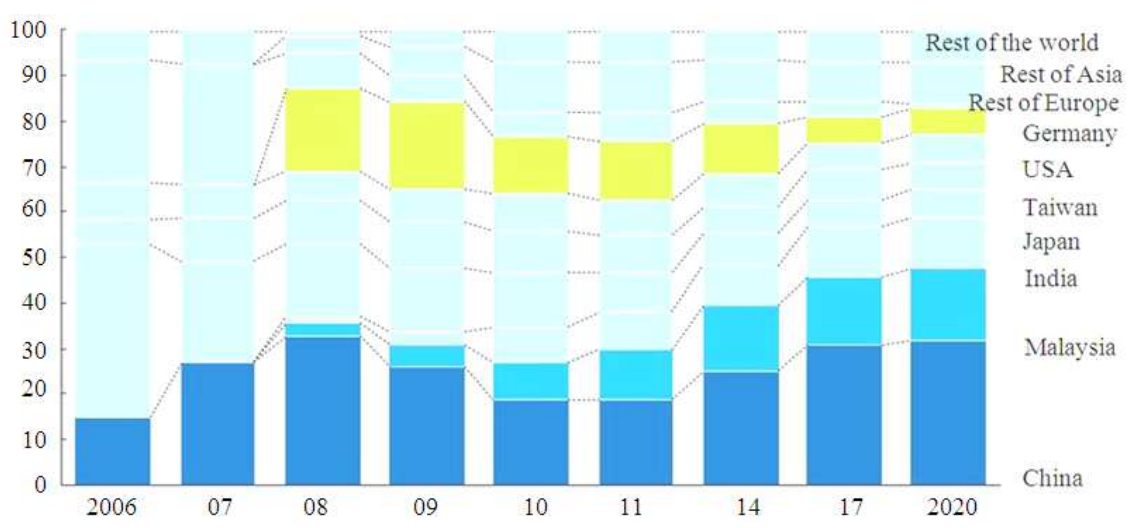

Fig. 1. Malaysia share in global solar industry in 2020 (Archives, 2010)

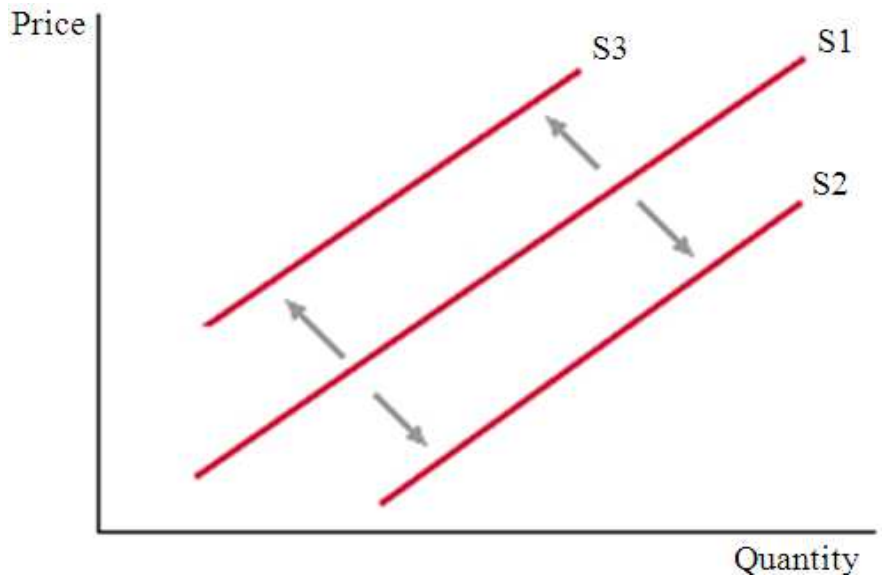

Fig. 2. The rate of changes in the supply price

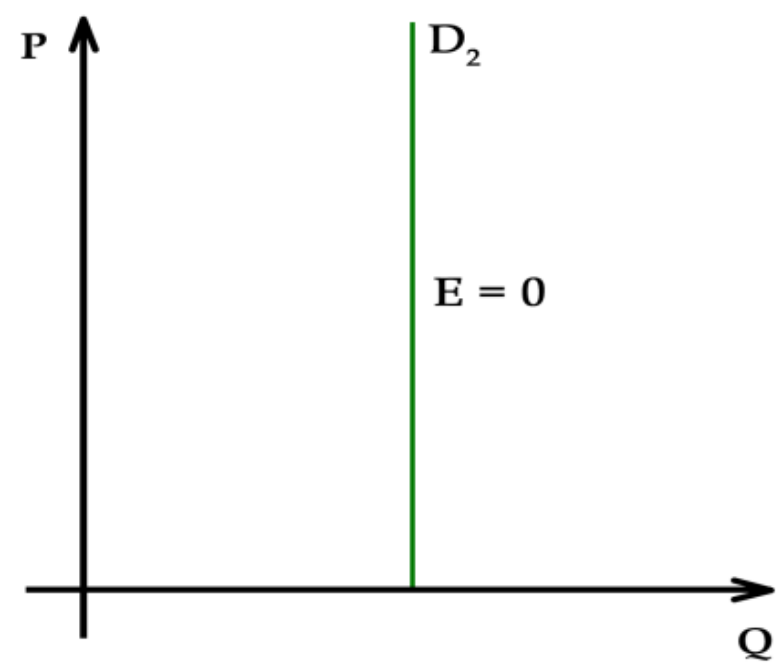

Fig. 3. Elasticity of prices of solar cell 


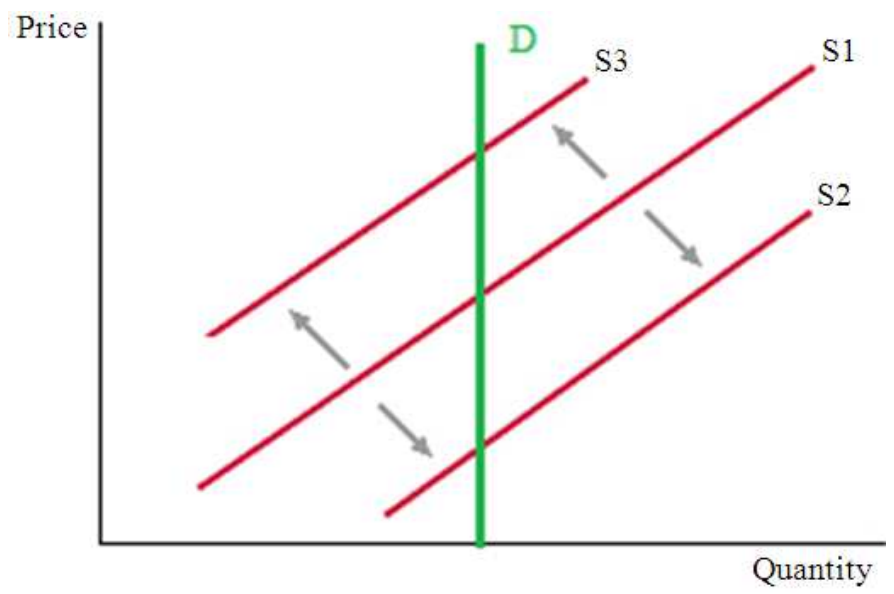

Fig. 4. Confluence of solar cell elasticity and solar cell supply

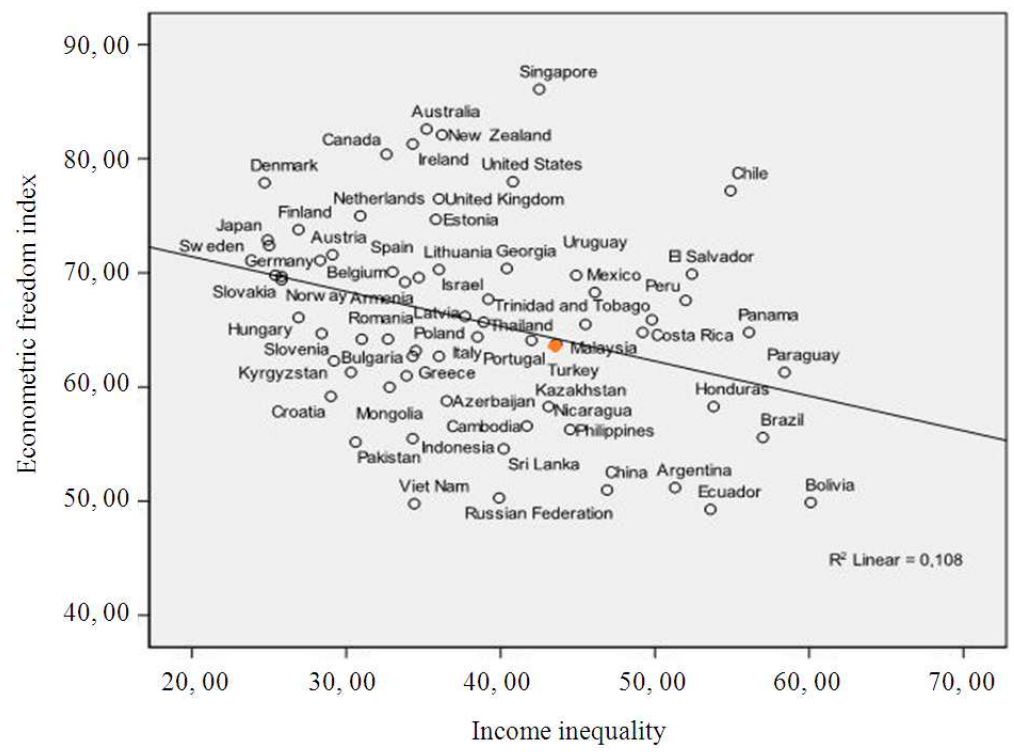

Fig. 5. Income inequality in a global comparison (Florida, 2010)

\section{CONCEPTUAL MISTAKES IN WORLD BANK REPORT}

As the World Bank report has correctly stated on its page 13 , the number one concern is the added value generated in the industry, not the industry's high-tech, medium-tech or low-tech. But on pages 14 and 15 of the report, higher per capita GDPs of Brazil, Argentina, Mexico and Chile are explicitly reported as the reason for the lower share of high-tech in their industrial export, while in the same graph there are other countries like
Pakistan, Bangladesh, Indonesia, Thailand and China which suffer from lower shares of export despite their lower per capita GDPs. Due to the population diversity of countries, per capita GDP is not, generally speaking, an appropriate index for comparing countries and their success rate making production policies.

Figure 5 shows that in all the four countries, Brazil, Argentina, Chile and Mexico, are in much lower positions for the fair distribution of income than Malaysia, although they have been more successful than this country in average per capita GDPs. 
Here it can be concluded that not only does the GDP per capita have anything to do with high-tetchiness or low-tetchiness of a country's export, but the GDP per capita is not also an appropriate index for evaluating countries' success in making production policies, surely one of the major objectives of macroeconomics is the fair distribution of wealth and income in a country. What is important here is Gini coefficient, which is an index for success or failure of a production policy in a country. According to the latest report released by the World Bank in 2011, Argentina's Gini coefficient is of $44.5 \%$, Chile's is $52.1 \%$ and that of Mexico is $48.3 \%$. This is while the report notes that Malaysia's Gini coefficient is $46 \%$, indicating that the Malaysian economic policies has been far more successful in distributing wealth than those of other countries listed in the World Bank study.

Through the World Bank study currently (such as page 16) emphasized on GDP per capita. But, per capita income is not the only criterion for evaluating the personal income and it is not either an appropriate index for evaluating welfare. Yet, according to the same report, over the 30 years from 1967 to 1997, Malaysians' per capita income has reached to US $\$ 4,400$ per year from US $\$ 790$ per year, which reflects the success in planning and sustainable development in the country. This is in such a condition that according to Malaysia's Ninth Development Plan (2006-2010), the main objective of the country in presenting economic programs is not making a limited number of people in the society rich (just like what has happened in some South American countries). Rather it is maintaining justice in the distribution of wealth and removing income inequalities.

In this report, Malaysia's economic growth has been going down repeatedly compared with that of South Korea. On its page 18, writers have emphasized four decades ago, Korea was much poorer than Malaysia, but today, Korea's per capita income is three times more than that of Malaysia. Steinberg (2009) believes that the shadows of North Korea and China in the back are the main reasons (Steinberg, 2009) for the United States' tendency to South Korea and as a result its rapid economic growth. With the nuclear trend that North Korean has taken in the years after 2000, the United States'interestin equipping South Korea technologically and economically has increased and the United States' great market has been made accessible to South Korea without any restrictions (Steinberg, 2009).

Paying attention to the history of Political Economy in South Korea helps to uncover the rapid growth of this country. South Korea was the place which came to Americans' attentions for the first time in 1945, before the U.S.-Vietnam War (Steinberg, 2009). During the war, however, the admirable role of South Korean in supporting the forces and weapons of the U.S. caused that the Vietnam War to become the country's first period of economic growth (Chung, 2007). By1971 only, the United States paid a loan of about $\$ 4$ billion to South Korea for forming it's the industries (Mongabay, 2013). Over these years, it is obvious that South Korea's economic growth neither has been similar to Malaysia's politically peaceful process independence nor has it obeyed economic formulas of the market, so it cannot be used as an appropriate example for comparing the economic growth of the countries.

After enumerating some sections of the Malaysian industries' master plan and making some suggestions about increasing the added value of industries in Malaysia and their forward move in accordance with the value chain, the page 32 of the World Bank's report brings an example on this country's forest related industries and surprisingly without any analysis and presenting any evidence, on its next page it claims that a part the Finnish Forest Industries is an ideal model for the Malaysian industries. In the next paragraph (of p. 23 of the report) it is also asserted that Malaysia should try so that it can develop its solar and medical devices industries through following Finland Forest Industries. Apart from the fundamental differences between Malaysia's solar and medical devices industries discussed previously, the similarities between the production structure of Finland Forest Industries and the solar industry's competitive market is so is little that it would be difficult to find some things in common between these two and it is unclear that with what premises and background the writer of report have arrived to such a conclusion that the best example for the structure of industries in Malaysia is following the structure of the Finnish Forest Industries.

South Korea and India have been named as Malaysia's regional counterparts in several parts of the World Bank's report including its page 43. But Malaysia belongs to the geographical area of Southeast Asian 
countries. South East Asia consists of 13 countries which are geographically located in the east of India and south of China. India belongs to the geographical area of South Asian countries which consists of this country together with 7 neighboring countries and South Korea next to China, Japan and five other countries, regarded East Asian countries.

\section{CONCLUSION}

Contrary to what writers of the World Bank's report on the Malaysian Solar Industry have frequently said, this report is not a research plan about this industry; but, as stated on the last paragraph of page 4 of the report it is a policy adjustment which compares the general policies of the World Bank, with statistics on the Malaysian solar industry. As it is mentioned in the third paragraph of page 7 , the World Bank unfortunately believes in an "intellectual property right" for "PV Global Leaders". Therefore, the draft report is such that non-industrial countries leave the upstream the solar industry to industrial countries. On the other hand, the presented study lacks some basic factors for decision-making, like the elasticity indices for different phases of the solar industry and risk analysis of the motion from one chain to another. The collected data and future decision makings are discussed not on the basis of the dynamic conditions of the Malaysian solar industry, but according to its static points. Therefore the presented proposals do not enjoy the required validity and reliability for conducting the Malaysian solar industry to desirable goals. Proposals such as the vertical integration of the production chain without analyzing the risks which may result from this action are dangerous and unscientific measures. Besides this, not only will encouraging Malaysia to moving towards downstream industries for achieving more added value decrease the security of future investments in this industry in Malaysia, but it also will raise the price of the final products and create crisis in the industry in the event of imbalance. The writers of the report seem to have not had the opportunity to get familiar with Malaysia's prospect, economic plans, geographical location and regional rivals and yet they have tried offer their proposal in an artificial atmosphere through ignoring the existing tariff and non-tariff barriers in the realm of international trade.

\section{ACKNOWLEDGMENT}

I am pleased to thank The Centre for Engineering Education Research, University Kebangsaan Malaysia and Prof. Azami Zaharim for their helpful supports.

\section{REFERENCES}

Alexander, C., 2009. Market Risk Analysis, Value at Risk Models, 1st Edn., Wiely, New York, ISBN-10: 978-0-470-99799-4, pp: 1652.

Archives., 2010. Malaysia can become third largest solar cells producer. The star online.

Asche, F., O. Flaaten and J.R. Isaksen, 2002. Derived demand and relationships between prices at different levels in the value chain: A note. J. Agric. Econ., 53: 101-107. DOI: 10.1111/j.1477-9552.2002.tb00008.x

Bakhtyar, B., A. Zaharim, K. Sopian, O. Saadatian and N. Ludin, 2012a. The effects of feed in tariff on foreign direct investment in Malaysia. Proceeding of the IASME International Conference on ENERGY and Environment Technologies and Equipment, (EEETE'12), Zlin, Czech, Republic.

Bakhtyar, B., A. Zaharim, N. Asim, K. Sopian and C.H. Lim, 2012b. Renewable energy in Malaysia: Review on energy policies and economic growth. Recent Adv. Energy, Environ. Econ. Dev.., 1: 146-153.

Bakhtyar, B., K. Sopian, M.Y. Sulaiman and S.A. Ahmad, 2013a. Renewable energy in five South East Asian countries: Review on electricity consumption and economic growth. Renewable Sustain. Energy Rev., 26: 506-514. DOI: 10.1016/j.rser.2013.05.058

Bakhtyar, B., K. Sopian, A. Zaharim, E. Salleh and C.H. Lim, 2013b. Potentials and challenges in implementing feed-in tariff policy in Indonesia and the Philippines. Energy Policy. DOI: 10.1016/j.enpol.2013.05.034

Bradford, T., M. Gobbo, J. Varney, A. Watkins and P. Schellekens, 2011. Moving up the Value Chain: A Study of Malaysia's Solar and Medical Device Industries. World Bank, New York.

Chung, Y., 2007. South Korea in the Fast Lane: Economic Development and Capital Formation. 1st Edn., Oxford University Press, ISBN-10: 0198043627, pp: 480.

Florida, R., 2010. Free, Tolerant and Happy. Creative class. 
Hull, B., 2005. The role of elasticity in supply chain performance. Int. J. Product. Econ., 98: 301-314. DOI: $10.1016 /$ j.ijpe.2004.09.013

Johnson, K. and C. Sweet, 2012. Solar-Trade Fight Flares Up. Wall Street J.

Porter, M., 1985. Competitive Advantage: Creating and Sustaining Superior Performance, 1st Edn., Reprint, New York: Simon and Schuster, ISBN-10: 1416595848, pp: 592.

Shapley, L.S. and M. Shubik, 1969. On market games. J. Econ. Theory, 1: 9-16. DOI: 10.1016/00220531(69)90008-8
Sheng, A., 2009. From Asian to global financial crisis. Cambridge University Press, New York.

Sopian, K., 2010. Malaysia Solar Energy Technology Roadmap. In: Mosti, Johor Baharu.

Mongabay, S.K.H., 2013.

Steinberg, D.J., 2009. The Republic of Korea: Pluralizing Politics. Berkly Center. 